\title{
Genetic diversity of Chondrostereum purpureum (Pers.) Pouzar causing silverleaf disease on blueberries in Chile
}

\section{Diversidad genética de Chondrostereum purpureum (Pers.) Pouzar causante del plateado en arándano en Chile}

\author{
Carmen Rojo ${ }^{1}$, Viviana Becerra $^{1 *}$, Andrés France ${ }^{2}$, Mario Paredes $^{1}$, Alan buddie $^{3}$ \& Monica Balzarini $^{4}$ \\ ${ }^{1}$ Laboratorio de Biotecnología, Instituto de Investigaciones Agropecuarias (INIA), Avenida Vicente Méndez 515, Chillán, Chile. \\ ${ }^{2}$ Laboratorio de Fitopatología, Instituto de Investigaciones Agropecuarias (INIA), Avenida Vicente Méndez 515 Chillán, Chile. \\ ${ }^{3} \mathrm{CABI}$, Bakeman Lane, Egham, Surrey, TW209TY, United Kingdom. \\ ${ }^{4}$ Universidad Nacional de Córdoba, Avenida Enrique Barros esq. Los Nogales, Ciudad Universitaria, CP: 5000, Córdoba, \\ Argentina. \\ *vbecerra@inia.cl
}

\begin{abstract}
Blueberry (Vaccinium corymbosum L.) in Chile is being affected by silver disease whose causative agent is Chondrostereum purpureum (Pers.) Pouzar. This fungus causes a decrease in the yield of the fruit and the death of the plant. So far, this disease has not been reported in the literature attacking blueberry plants in Chile. The main objective of this research was to characterize genetically the populations of Ch. purpureum at molecular level using the ITS-RFLP markers. The results of the ITS-RFLP indicate a low level of diversity in the Chilean populations of Ch. purpureum. When analyzing the isolates collected in blueberry, two large groups were configured in the dendrogram. The first one grouped 49 isolates with the same molecular profile and in the second cluster there was a greater diversity among the isolates. On the other hand, when we analyzed Ch. purpureum isolates collected in other hosts, 12 isolates constituted a group with identical molecular profile with the 49 isolates collected from blueberry. Analysis of variance of the molecular data showed that there were no statistical differences between Ch. purpureum collected in different areas or in different hosts.
\end{abstract}

KEYwORDS: Chondrostereum purpureum, ITS-RFLP diversity, molecular markers.

\section{RESUMEN}

El arándano en Chile está siendo afectado por la enfermedad del "plateado" cuyo agente causal es Chondrostereum purpureum (Pers.) Pouzar. Este hongo produce una disminución en el rendimiento de la fruta y la muerte de la planta. Hasta ahora, esta enfermedad no se ha reportado en la literatura atacando plantas de arándano en Chile. El objetivo principal de esta investigación fue caracterizar genéticamente las poblaciones de $\mathrm{Ch}$. purpureum a nivel molecular utilizando los marcadores ITS-RFLP. Los resultados de los ITS-RFLP indican un bajo nivel de diversidad en las poblaciones Chilenas de Ch. purpureum. Al analizar los aislados recolectados en arándano se configuraron en el dendrograma dos grandes grupos. El primero de ellos agrupó 49 aislamientos con el mismo perfil molecular y en el segundo cluster hubo una mayor diversidad entre los aislados. Por otro lado, cuando se analizaron aislados de Ch. purpureum recolectados en otros huéspedes, 12 aislados constituyeron un grupo con idéntico perfil molecular con los 49 aislados recolectados de arándano. El análisis de varianza de los datos moleculares mostró que no había diferencias estadísticas entre Ch. purpureum recolectado en zonas diferentes o en diferentes huéspedes.

Palabras clave: Chondrostereum purpureum, diversidad de ITS-RFLP, marcadores moleculares.

\section{INTRODUCTION}

Blueberry (Vaccinium corymbosum L.) is the fastest growing fruit crop in Chile based on both area and production. Currently, blueberry has a planted area of approximately
14,506 hectares and a production of $81,000 \mathrm{t}$ mainly for export (ODEPA 2014). Chilean blueberry production has a competitive advantage due to its off-season production that allows it to offer this product to the main fresh markets in the Northern Hemisphere (United States, Canada, and some 
European countries) when there is no fresh fruit available. In this context, Chile is the second most important producer and main exporter of fresh blueberry fruit worldwide (PROCHILE 2011, ODEPA 2014).

Agroclimatic conditions, especially in the central and southern zone of the country, are favourable to establish and produce an excellent quality blueberry fruit for the international market and compete favourably with others countries and other fruit species in these regions. Currently, $89 \%$ of the total blueberry production is concentrated in the central-southern $(8,646$ has) and southern regions $(4,221$ has) of the country (ODEPA-CIREN 2014). The increasing interest for producing blueberry in the country has led to the exploration of new agroecological areas and the possibility of being attacked by new pathogens.

In Chile, blueberry is attacked by various diseases, such as Agrobacterium tumefaciens (Smith \& Townsend 1907) Conn, 1942, Armillaria mellea (Vahl) P. Kumm., Botrytis cinerea Pers. ex Fr., Diaporthe spp. (Elfar et al. 2013), Neofusicoccum spp. (Espinoza et al. 2009, Pérez et al. 2014), Phoma spp. (Cisterna \& France 2009), Phomopsis vaccinii Shear., and Phytophthora cinnamomi Rands. Since 2009, blueberry has been attacked by a new fungal disease that produces symptoms characteristics of the "silverleaf". These symptoms that were originated in the southern area, are detected right now, in the northern area of the country (France et al. 2009).

Currently, the causal agent of this disease has been identified as Chondrostereum purpureum (Pers.) Pouzar (Basidiomycota), using morphometric and molecular tools (France et al. 2009). Various studies indicate that $C h$. purpureum causes damage in other fruit and forest genera such as Prunus, Pyrus, Actidinia, and Rubus, and Salix and Populus, respectively (Farr et al. 2008). In 2014, Ch. purpureum was detected for the first time in blueberry in Oregon, EE.UU. (Seth Elkington, pers. com., Simplot Advisor, U.S.A.).

The symptoms of this disease present in the Chilean blueberry are similar to those described for Chondrostereum purpureum attacking larger fruit trees; where plants exhibit less vigour in the branches and a gradual change in their color from green to greyish or silver causing a xylem necrosis. These symptoms initially affect few branches and finally cover to the whole plant, when the presence of the disease is severe. The xylem necrosis is the result of a colonization of the xylem by the fungus that induces to the plant to break easily over time (France et al. 2009). These morphological damages are caused by the effects of an endopoligalacturonase (endoPG) toxin produced by the pathogen, which migrates through the xylem to the leaves; producing the detachment of the foliar lamina from the palisade parenchyma, producing an air chamber, which gives it a silver appearance due to the optical effect of light passing through this chamber (Torres et al. 2006).
Based on the information presented above, it is necessary to broad the morphological information of this fungus available, in order to know the level of the genetic diversity of this pathogen and to determine the genetic relationships among isolates, their geographic distribution; the cultivar susceptibility to this disease, and to develop a strategy of control to face this problem.

Considering this situation, PCR based on in vitro amplification of specific DNA sequences, such as the nuclear ribosomal DNA, could contribute to determine the genetic diversity of this pathogen. Ribosomal DNA (rDNA) has a high copy number, repeated in tandem, and that includes three genes, the $18 \mathrm{~S}, 5.8 \mathrm{~S}$, and $28 \mathrm{~S}$. These gene sequences are separated by two internal transcribed spacers (ITS), ITS1 and ITS2, with an estimated size of between 200 to 400 bases. These regions accumulate nucleotide mutations; when amplified by universal and/ or species-specific primers can be used to determine the genetic diversity among various organisms, including fungal populations (Gomes et al. 2002, O’Brien et al. 2005, Becerra et al. 2007 a, b, Taylor \& McCormick 2008).

The use of differential rates in nucleotide changes in nuclear ribosomal sequences has enabled the detection and comparison of fungus isolates at inter-and intraspecific levels attacking blueberries (Espinoza et al. 2008, Elfar et al. 2013, Pérez et al. 2014) and other species (Iturralde 2005, Toju et al. 2012). For example, the combined analysis of ITS and EF1- alfa gene sequences were able to identified five species of Diaphortein (Elfar et al. 2013) the ITS1-5.8S and ITS2$28 \mathrm{~S}$ to detect Neofusicoccum nonquaesitum (Pérez et al. 2014) and Pestalotiopsis ssp. and Truncatella sp. attacking blueberries in Chile (Espinoza et al. 2008). Using specific ITS primers for basidiomycetes (ITS1F-ITS4) Prewitt et al. (2008) was able to determine a monophyletic group in the Xylophagous fungal species. In another study, the rDNA amplification and Dra I enzyme DNA restriction was used for early detection, identification and differentiation of basidiomycete and ascomycete fungal species in wood chips (Adair et al. 2002). Up to now, there are no studies on the genetic diversity of Ch. purpureum in Chile.

The objectives of this work were to determine the genetic diversity of the Ch. purpureum populations, by ITS-RFLP.

\section{MATERIALS AND METHODS}

\section{Genetic MATERIAL AND GEOGRAPHIC Distribution}

A total of 119 isolates of Ch. purpureum were collected from 10 hosts, $84 \%$ of the isolates were obtained from blueberry and 16\% from other species such as Populus nigra L. (poplar), Acacia dealbata Link (acacia), Prunus avium L. (cherry), Prunus armeniaca L. (apricot), Prunus persica (L.) Batsch (peach), Eucalyptus globulus Labill. (eucalyptus), Malus $x$ domestica Borkh. (apple), Pistacia 
vera L. (pistachio) and Rosa chinensis Jacq. (rose) (Annex 1). The isolate Cho-391 was used as a reference line, since this isolate was identified as a Ch. purpureum in CABI, UK (France et al. 2009).

Ch. purpureum isolates were collected from plants that were displaying visible signs of silverleaf in the field orchards as described by France et al. (2009), then the isolates were morphometrically characterized at the Plant Pathology Laboratory at INIA Quilamapu, Chillán, to certify the presence of Ch. purpureum.

The isolates were collected from different locations during 2014: six (6) from the central zone (32 49'20"'S; $\left.71^{\circ} 03^{\prime} 48^{\prime \prime} \mathrm{W}\right), 30$ from the central-southern area and 83 from southern Chile (407'73"S; 73³0'12"W). Isolates were deposited at INIA Microbial Germplasm Bank (Annex 1) and the genetic study was conducted at the Biotechnology Laboratory, at INIA Quilamapu, Chillán.

\section{DNA EXTRACTION}

DNA was extracted from fungal mycelium of pure isolates culture grown on a solid nutrient malt agar (MA) medium (malt extract $20 \mathrm{~g}$, agar $20 \mathrm{~g}$, yeast extract $2 \mathrm{~g}$, distilled water to complete $1 \mathrm{~L}$ ) in Petri dishes incubated at $27{ }^{\circ} \mathrm{C}$. Mycelium maceration was done with liquid nitrogen and samples were incubated for $45 \mathrm{~min}$ with $700 \mu \mathrm{L}$ extraction buffer (100 mM Trizma (Invitrogen); $1.4 \mathrm{M} \mathrm{NaCl}$ (Sigma); $20 \mathrm{mM}$ EDTA (Sigma); 1\% Polivinilpirrolidone (Sigma); 2\% CTAB (Sigma); 1\% $\beta$-mercaptoetanol (Sigma); pH 8.0) at $65{ }^{\circ} \mathrm{C}$, an aliquot of $10 \mu \mathrm{L}$ proteinase $\mathrm{K}$ (Sigma) $(50 \mu \mathrm{g} /$ $\mathrm{ml}$ ) was added to each sample. Samples were cooled at room temperature and mixed twice with $2 / 3 \mathrm{v} / \mathrm{v}$ chloroform: isoamyl alcohol (Sigma) (24:1) and centrifuged at $5000 \mathrm{rpm}$ for 15 min (Eppendorf centrifuge 5804, Hamburg, Germany). The aqueous supernatant was transferred to a clean tube and DNA was precipitated with isopropanol (Sigma) and then incubated at $-20{ }^{\circ} \mathrm{C}$ over night. The DNA pellet was washed with $70 \%$ and $90 \%$ ethanol (Sigma), dried at room temperature, and suspended in TE solution (10 mM Tris; 1 mM EDTA; $\mathrm{pH}$ 8). Finally, DNA was treated with RNAse (Sigma) $(10 \mathrm{mg} / \mathrm{ml})$ and stored at $-20^{\circ} \mathrm{C}$ for future use.

DNA concentrations were measured using a UV-Vis Nanodrop 2000 spectrophotometer (Thermo Scientific, Wilmington Delaware) and concentrations were then standardised at $5 \eta \mathrm{g} \mu \mathrm{L}^{-1}$ in sterile distilled water. In addition, DNA quality was verified in a $1 \%(\mathrm{w} / \mathrm{v})$ agarose gel using $\lambda$ HindIII as a DNA ladder.

INTERNAL TRANSCRIBED SPACER ANALYSIS

For the genetic analysis of the isolates, universal primers, specific to the internal transcribed spacer (ITS) regions of the Basidiomycota, ITS1F and ITS4B were used to amplify the ITS1-5.8S-ITS2 for which protocols were adjusted on two Ch. purpureum isolates collected on blueberry (Gardes \& Bruns 1993).
Reaction conditions were performed in a $25 \mu \mathrm{L}$ total volume made up of $0.2 \mathrm{mM}$ dNTPs, $0.2 \mathrm{mM} \mathrm{ITS} 1 \mathrm{~F}$ and ITS4B primers, $1 \mathrm{x}$ of PCR buffer, $0.25 \mathrm{mM} \mathrm{MgCl}_{2}, 1 \mathrm{U}$ Taq DNA polymerase (Invitrogen), and $10 \eta \mathrm{g} \mu \mathrm{L}^{-1}$ of DNA template.

Amplification was performed in a DNA Engine DYAD ${ }^{\mathrm{TM}}$ thermocycler (MJ Research, Inc., Waltham Massachusetts) under the following conditions: 3 cycles of 1 min $20 \mathrm{~s}$ at 95 ${ }^{\circ} \mathrm{C}, 1 \mathrm{~min}$ at $37^{\circ} \mathrm{C}, 1 \mathrm{~min}$ at $72^{\circ} \mathrm{C}$, and 37 cycles of $35 \mathrm{~s}$ at $94{ }^{\circ} \mathrm{C}, 40 \mathrm{~s}$ at $40^{\circ} \mathrm{C}, 1 \mathrm{~min} 20 \mathrm{~s}$ at $72{ }^{\circ} \mathrm{C}$ with an elongation period of $10 \mathrm{~min}$ at $72{ }^{\circ} \mathrm{C}$, followed by a maintenance at $4{ }^{\circ} \mathrm{C}$.

Digestion of the amplified PCR products of four (4) randomly chosen strains was conducted in $20 \mu \mathrm{L}$ total volume, containing: $3 \mu \mathrm{L}$ amplified DNA product, $1 \mathrm{x}$ buffer (enzyme-specific buffer), and 5 to 8 units of restriction enzyme (made up to $20 \mu \mathrm{l}$ with sterile molecular grade $\mathrm{H}_{2} \mathrm{O}$ ). Samples were incubated at $37{ }^{\circ} \mathrm{C}$ for $2 \mathrm{~h}$ according to the manufacturer's instructions (Thermo Scientific). A total of 32 restriction enzymes were used that recognize different nucleotide digestion sequences: AccI, AluI, AseI, AvaII, BamHI, BglII, BstEII, DdeI, DraI, EcoRI, EcoRV, HaeIII, HhaI, HinfIII, HpaII, MboI, MseI, MspI, NdeII, NdeI, PstI, RsaI, Sau3AI, SacI, SacII, SpeI, SspI, TaqI, SinI, Tru9I, XbaI, and XhoI. Based on their performance, nine restriction enzymes were selected for genetic analysis of the 119 strains, using the reaction and amplification conditions as described previously.

Restriction fragments were separated on a $6 \%$ polyacrylamide gel $(20 \times 20 \mathrm{~cm})$ in $1 \times$ TBE buffer at $100 \mathrm{~V}$ for $3 \mathrm{~h}$ (Cole-Parmer vertical dual adjustable slab gel system; Vermon, II). The gel was stained with GelRed (Biotium) to visualize the DNA fragments under ultraviolet light (G: Box ICHEMI XR image analyser; Syngene Co., Cambridge, United Kingdom). Fragment sizes were determined by visual comparison to 10 and $100 \mathrm{bp}$ DNA ladders.

\section{DATA ANALYSIS}

Band profiles were recorded for the $119 \mathrm{Ch}$. purpureum isolates. Polymorphic bands were considered as binary characters, and scored as " 1 " if present or " 0 " if absent, for each marker. Genetic similarity between pairs was estimated by Jaccard's coefficient to transform values into genetic distance, which was defined as the square root of the onecomplement of the similarity $(\sqrt{ } 1-\mathrm{S})$. The distance matrix was analysed by metric multidimensional scaling (MDS) as the grouping technique (PC analysis). A hierarchical clustering technique using the UPGMA (Unweighted Pair Group Method with Arithmetic Mean) method was used; it was selected because it provided the highest cophenetic correlation. Genetic distances were subjected to an analysis of molecular variance (AMOVA) to determine the statistical significance of the data (Excoffier et al. 1992). The existence of specific band patterns was determined with the ITS-RFLPs to identify some isolates. 
Statistical analysis of the data was performed with the InfoGen version 2013 FCA statistical programme (National University of Cordoba, Argentina) (Balzarini \& Di Rienzo 2013).

\section{RESULTS}

DiVERSITY PARAMETERS OF CHONDROSTEREUM PURPUREUM COLLECTED IN BLUEBERRY

The ITS1F and ITS4B primers were used to amplify the ITS region in $100 \mathrm{Ch}$. purpureum isolates collected only from blueberry. In each case only a single fragment was obtained. Nine out of 32 enzymes detected different levels of polymorphism and they were selected for the analysis. These nine restriction enzymes were: AluI, DdeI, DraI, EcoRI, HhaI, Mbol, MseI, SpeI, and Taq.

These nine (9) restriction enzymes detected a total 67 bands from $100 \mathrm{Ch}$. purpureum isolates, of which $90 \%$ were polymorphic. A total of 70 isolates presented an identical pattern for the ITS/restriction enzyme combinations used in this study.

The HhaI restriction enzyme generated the highest number of bands (13) and banding pattern (8), followed by MboI (9), EcoRI (Fig. 1) and TaqI (8) (Table 1). The highest values of polymorphic information content was obtained by the restriction enzymes $M s e \mathrm{I}(\mathrm{PIC}=0.15)$ and $M b o \mathrm{I}(\mathrm{PIC}=$ $0.10)$; both being the most informative restriction enzymes in this study. The lowest probability that two isolates share the same band (PRSA) value was $1 \times 10^{-4}$ for the restriction enzymes MseI and $4.9 \times 10^{-3}$ for SpeI. These markers had a high confidence level for identifying Ch. purpureum strains. On the contrary, it was shown that the restriction enzyme AluI has no discriminatory ability $(\mathrm{PMF}=0)$ and its polymorphic information content was very low for the isolates collected on blueberry $(\mathrm{PIC}=0.02)($ Table 1$)$.

Cluster analysis based on Genetic Distance of CHONDROSTEREUM PURPUREUM ISOLATES

The PC analysis using the Jaccard's similarity coefficient (Fig. 2) explained 52\% of total variability. The PC1 and PC2, explains $33.5 \%$ and $18.5 \%$ of the variability, respectively, for the nine polymorphic restriction enzymes.

Isolates collected from blueberries were widely distributed on PC1, about half were located on the negative side and the rest at the positive PC1 coordinate, thus two main groups can be identified. In addition, a group of 48 Ch. purpureum isolates were located at the same point along with Cho 391, used as a reference strain; indicating the genetic identity of these isolates in this study. All these isolates came from the central-south and south zone of the country. For the PC2, the isolates were also widely distributed along the axis.

On the other hand, cluster analysis using the UPGMA method led to a dendrogram with a cophenetic correlation index of 0.99 , which indicates that the dendrogram distances reflected original distances (Fig. 3). The observed genetic distances among isolates ranged from 0 to 1 (mean 0.33 ). Two main groups can be observed in the dendrogram, the lower cluster included 51 isolates, which come from the central $(2 \%)$, central-south $(22 \%)$ and south zone $(76 \%)$, clustered at the same genetic distance, along with the reference strain Cho-391. Most of them (49) had the same molecular profile for the nine restriction enzymes evaluated. Only two strains Cho-816 and Cho-882 seemed to be slightly different (Fig. 3).

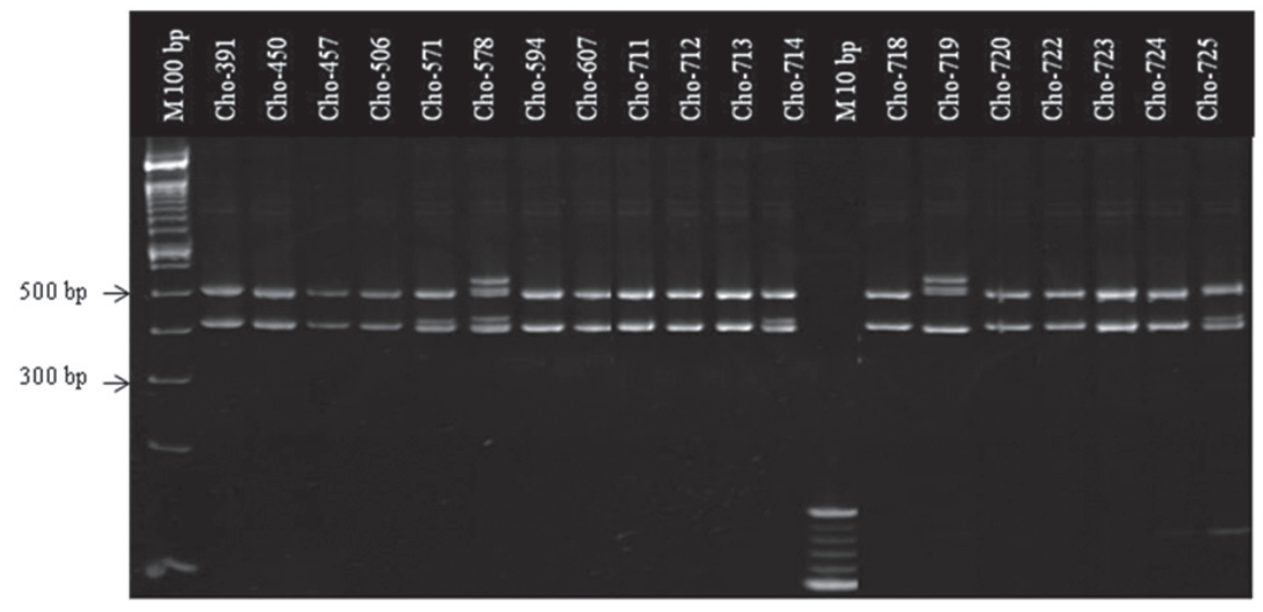

FiguRE 1. Example of ITS-RFLP band patterns from 19 Chondrostereum purpureum isolates generated by EcoRI restriction enzyme. M100bp and 10bp= Standard molecular weight. / Ejemplo de patrón de bandas ITS-RFLP band de 19 aislados de Chondrostereum purpureum detectados con la enzima de restricción EcoRI. Estándares de peso molecular: M100bp y 10bp. 
TABLE 1. Total (TB), polymorphic (PB) and monomorphic bands (MB), proportion of polymorphic loci (PPL), polymorphic information content (PIC) and probability of two individuals randomly sharing the same alleles detected by ITS-RFLP characterisation of Chondrostereum purpureum collected from blueberry. / Número de bandas total (TB), polimórficas (PB), monomórficas (MB), proporción de loci polimórficos (PPL), contenido de información polimórfica (PIC) y probabilidad de que dos individuos compartan alelos al azar (PRSA), detectados por la caracterización de Chondrostereum purpureum recolectado en arándano, mediante ITS-RFLP.

\begin{tabular}{lccccccc}
\hline $\begin{array}{l}\text { ReStRICTION } \\
\text { ENZYME }\end{array}$ & TB & PB & MB & PPL (95\%) & PIC & $\begin{array}{c}\text { BANDS } \\
\text { PRESENT (\%) }\end{array}$ & PRSA \\
\hline AluI & 7 & 7 & 0 & 0.00 & 0.02 & 43.00 & $3,7 \times 10^{-1}$ \\
DdeI & 4 & 4 & 0 & 0.25 & 0.07 & 28.04 & $3,0 \times 10^{-2}$ \\
DraI & 7 & 7 & 0 & 0.29 & 0.08 & 31.14 & $1,0 \times 10^{-2}$ \\
EcoRI & 8 & 7 & 1 & 0.25 & 0.07 & 28.75 & $3,4 \times 10^{-2}$ \\
HhaI & 13 & 11 & 2 & 0.23 & 0.07 & 25.62 & $5,5 \times 10^{-2}$ \\
MboI & 9 & 6 & 3 & 0.22 & 0.10 & 26.44 & $2,5 \times 10^{-2}$ \\
MseI & 7 & 6 & 1 & 0.43 & 0.15 & 52.57 & $1,0 \times 10^{-4}$ \\
SpeI & 4 & 4 & 0 & 0.25 & 0.06 & 50.88 & $4,9 \times 10^{-3}$ \\
TaqI & 8 & 8 & 0 & 0.13 & 0.05 & 26.02 & $2,0 \times 10^{-3}$ \\
Total & 67 & 60 & 7 & & & 33.01 & $5,5 \times 10^{-18}$ \\
\hline
\end{tabular}

TB: Total bands, PB: Polymorphic bands, MB: Monomorphic bands, PPL (95\%): Proportion of polymorphic loci at 95\%, PIC: Polymorphic information content, BP (\%): Bands present, PRSA: Probability of two individuals randomly sharing the same allele (band). / TB: Bandas totales, PB: Bandas polimórficas, MB: Bandas monomórficas, PPL (95\%): Proporción de loci polimórficos a 95\%, PIC: Contenido de información polimórfica, BP (\%): Bandas presentes, PRSA: Probabilidad de dos individuos compartiendo aleatoriamente el mismo alelo (banda).

The second group showed a higher genetic distance for the ITS-RFLP evaluated. This group clustered 49 isolates. The majority of the strains came from the southern (88\%) and the central-southern region (12\%). Within this group, the isolates presented several molecular profiles. This clustering of isolates based on Jaccard's coefficient corroborates the results found in the PC analysis of isolates represented in the biplot graph (Fig. 2).

Finally, the analysis of molecular variance (AMOVA) showed no statistical differences between Ch. purpureum collection zones $(p=0.425)$ and between the locations within the same zone $(\mathrm{p}=0.803)$ (Table 2).

GENETIC RELATIONSHIPS BETWEEN CHONDROSTEREUM PURPUREUM COLLECTED FROM BLUEBERRY AND OTHER HOSTS

The dendrogram of the complete collection of the 119 Ch. purpureum isolates that came from blueberry and 10 woody species, clustered all together the isolates with a cophenetic correlation index of 0.99 (Fig. 4). Most of the isolates collected from blueberry presented same genetic distance compared with those collected in other hosts (Fig. $3)$. Thus, the lower branch of the dendrogram showed 63 out of 119 Ch. purpureum isolates with the same genetic profile. Twelve of these isolates came from different hosts, such as poplar, apricot, peach, eucalyptus, apple, pistachio and rose. Again, isolates Cho-816 and 882, collected from blueberry were grouped at a slightly greater genetic distance (Fig. 4) from the others. In the upper cluster of the dendrogram, seven isolates collected on apple, cherry, peach and Acacia were widely distributed along with the isolates collected from blueberry (Fig 4).

For the group of isolates collected in blueberry, the confidence interval of the Shannon-Weaver (ShaW) genetic diversity index, using the percentile method, was 3.3-3.4 at a fixed $95 \%$ confidence level. The estimated ShaW index for the group of isolates from other host species (not blueberry) was 3.3; this indicated that this group has about the same diversity than the blueberry isolates.

The AMOVA performed for the molecular data coming from the two fungal host categories (blueberry and other species) (Table 3) did not show significant statistical difference $(\mathrm{p}=0.960)$.

The PC analysis of the types of Ch. purpureum host based on the ITS-RFLP molecular data, showed $56.8 \%$ that the total variability was explained by $\mathrm{PC} 1$; this indicated that the molecular profiles of the blueberry isolates were different from the molecular profiles of isolates from species such as Acacia dealbata, Populus nigra, Prunus armeniaca, Prunus persica, Eucalyptus globulus, Pistacia vera L., Rosa chinensis, and Prunus avium, which were very similar to each other. On the other hand, PC 2 explained a $26 \%$ of the variability and allowed to separate the isolates collected from Malus $x$ domestica Borkh from the other $C h$. purpureum hosts. 
Genetic diversity of Chilean Chondrostereum purpureum: RoJo, C. ET AL.

TABLE 2. Analysis of molecular variance (AMOVA) for ITS data between collection zones of Chondrostereum purpureum from blueberry plants. / Análisis de varianza molecular (AMOVA) para los datos de ITS entre zonas de recolección de Chondrostereum purpureum desde plantas de arándano.

\begin{tabular}{lcccccc}
\hline Source OF VARIATION & df & SS & MS & P value & $\begin{array}{c}\text { Variance } \\
\text { COMPONENTS }\end{array}$ & \% VARIATION \\
\hline Zones & 2 & 147.50 & 73.75 & 0.425 & 0 & 0 \\
Zones> Region & 3 & 105.54 & 35.18 & 0.803 & 0 & 0 \\
Within-zone & 94 & 8601.56 & 91.51 & 0.810 & 91.51 & 100 \\
Total & 99 & 8854.59 & 89.44 & & 91.51 & 100 \\
\hline
\end{tabular}

df: degrees of freedom, SS: sum of squares, MS: mean squares. $\mathrm{P} \leq 0.05$. / df: grados de libertad, SS: suma de cuadrados, MS: cuadrados medios. $\mathrm{P} \leq 0,05$.

TABLE 3. Analysis of molecular variance (AMOVA) of ITS-RFLP from Chondrostereum purpureum collected from blueberry and other woody species. / Análisis de la varianza molecular (AMOVA) de ITS-RFLP de Chondrostereum purpureum recolectado desde arándano y otras species leñosas.

\begin{tabular}{lcccccc}
\hline $\begin{array}{l}\text { SourCE OF } \\
\text { VARIATION }\end{array}$ & DF & SS & MS & P VAlue & $\begin{array}{c}\text { VARIANCE } \\
\text { COMPONENTS }\end{array}$ & \% VARIATION \\
\hline Host & 1 & 0.56 & 0.56 & 0.960 & 0 & 0 \\
Within-host & 117 & 1062.52 & 9.08 & 0.845 & 9.08 & 100 \\
Total & 118 & 1063.08 & 9.01 & & 9.08 & 100 \\
\hline
\end{tabular}

df: degrees of freedom, SS: sum of squares, MS: mean squares. $\mathrm{P} \leq$ 0.05. / df: grados de libertad, SS: suma de cuadrados, MS: cuadrados medios. $\mathrm{P} \leq 0,05$.

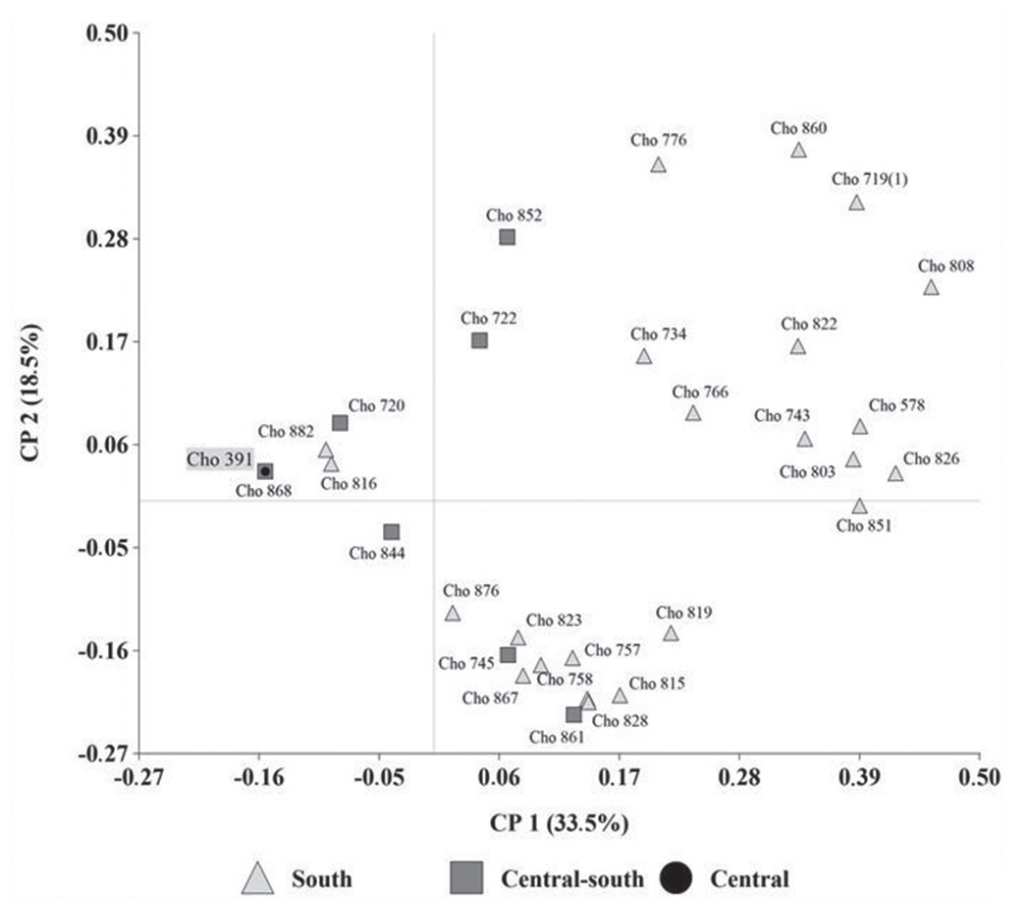

FIgURE 2. Principal Coordinates Analysis from ITS-RFLP evaluation of Chilean Chondrostereum purpureum isolates collected from blueberry plants. Jaccard's coefficient. / Análisis de Coordenadas Principales de ITS-RFLP de aislados Chondrostereum purpureum recolectados desde plantas de arándano. Coeficiente de Jaccard. 


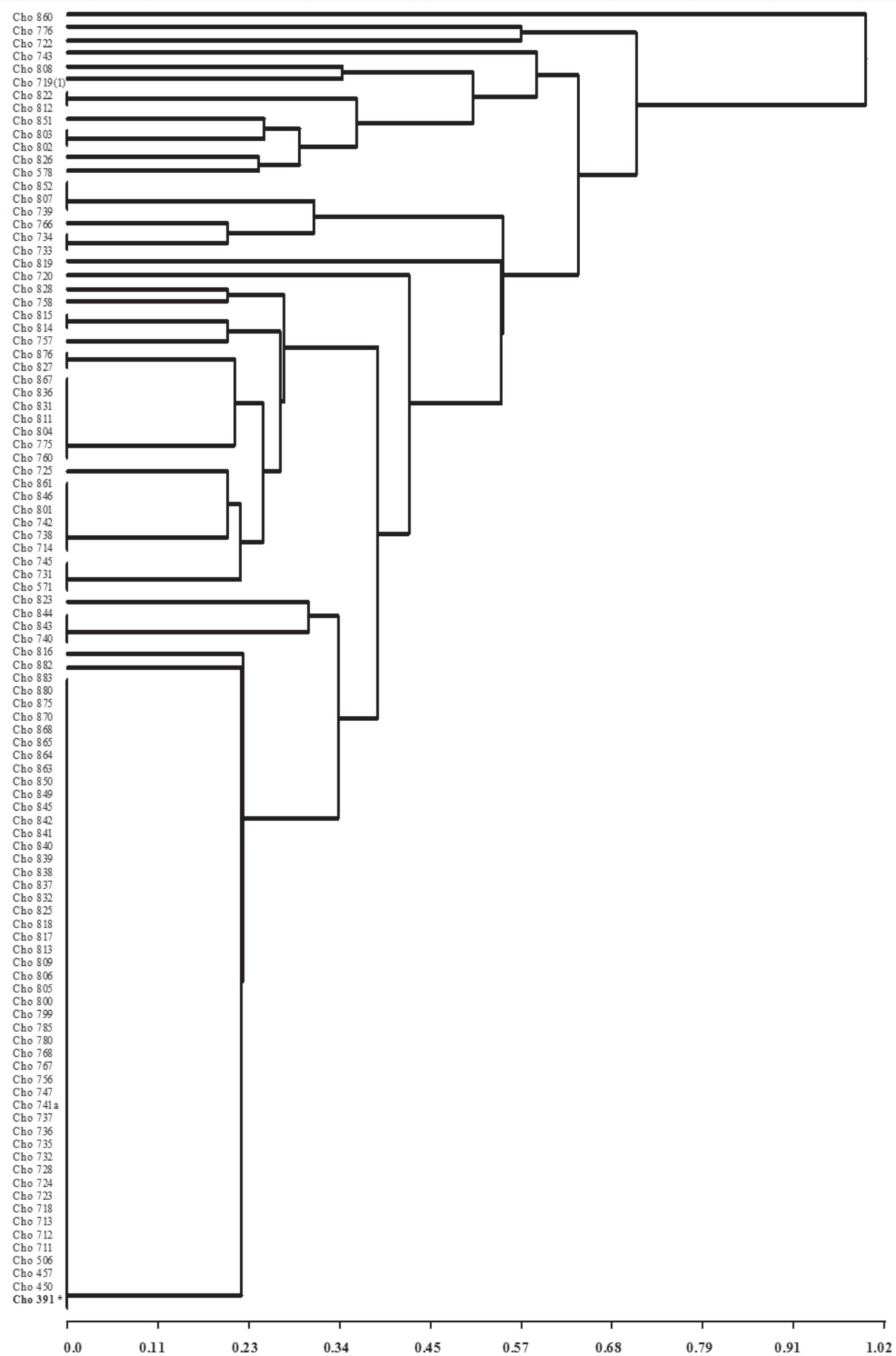

FIGURE 3. Dendrogram from ITS-RFLP analysis of Chilean Chondrostereum purpureum isolates collected from blueberry plants. Jaccard's coefficient. *Cho 391: reference C. purpureum isolate. / Dendrograma del análisis ITS-RFLP de aislados Chondrostereum purpureum recolectados desde plantas de arándano. Coeficiente de Jaccard. *Cho 391: Aislado de referencia. 


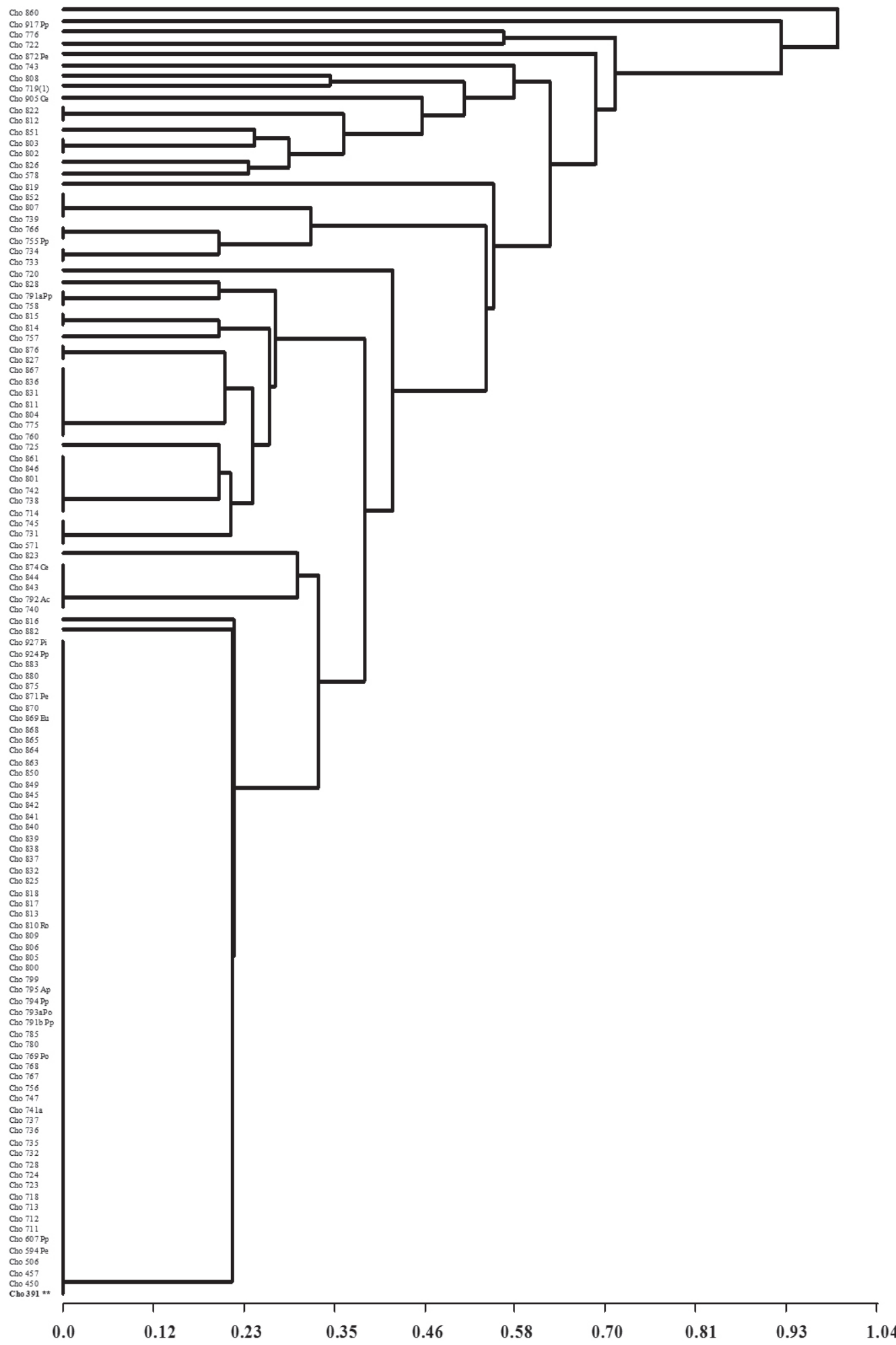

FIGURE 4. Dendrogram from ITS-RFLP analysis of Chilean Chondrostereum purpureum isolates collected from blueberry plants and other woody plants. Jaccard's coefficient. / Dendrograma del análisis ITS-RFLP de aislados Chondrostereum purpureum recolectados desde plantas de arándano y de otras especies leñosas*. Coeficiente de Jaccard.

*Hosts: Po: poplar, Ar: acacia, Ce: cherry, Ap: Apricot, Pe: peach, Eu: eucalyptus, Pp: apple, Pi: pistachio, Ro: rose. Huésped: Po: álamo, Ar: aromo, Ce: cereza, Ap: albaricoque, Pe: durazno, Eu: eucalipto, Pp: manzana, Pi: pistacho, Ro: rosa.

** Cho 391: reference C. purpureum isolate. / Cho 391: Aislado de referencia. 


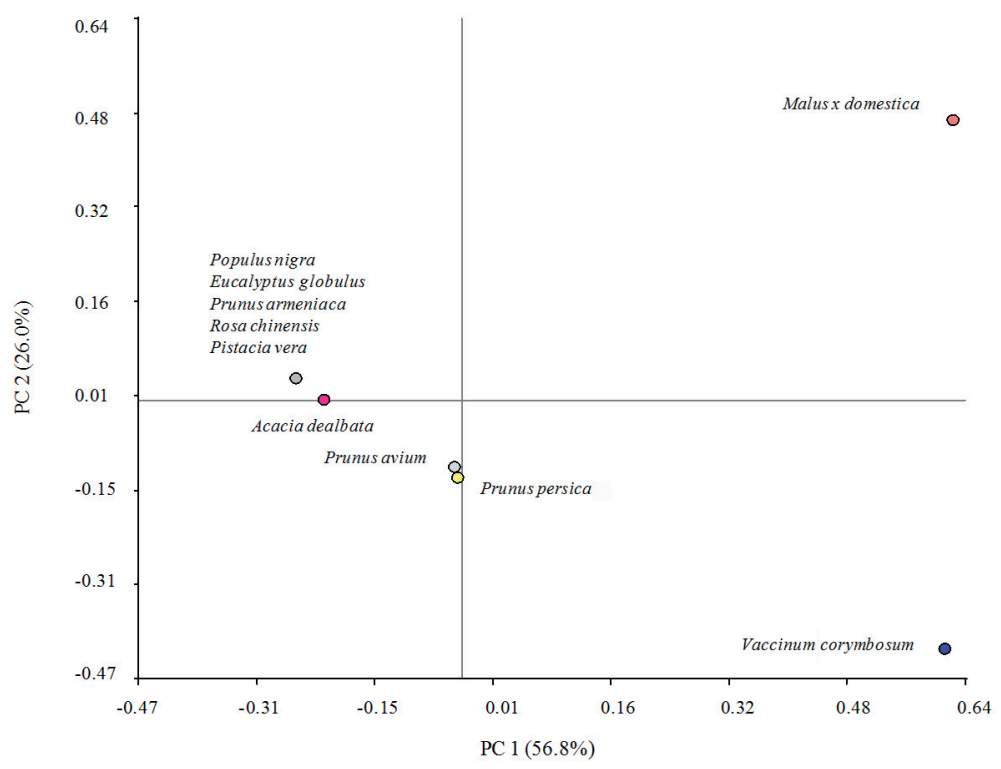

FIGURE 5. Principal coordinates analysis obtained with ITS markers for isolates of Chondrostereum purpureum collected in different woody species. / Análisis de Coordenadas Principales obtenido con marcadores ITS en aislados de Chondrostereum purpureum recolectados en diferentes especies leñosas.

\section{DISCUSSION}

This is the first study to examine Chilean genetic diversity of Ch. purpureum using ITS-RFLP of the ribosomal DNA. The isolates of this fungus included in this study had a good representation because they were collected from orchards of the whole area where the specie is planted in Chile and the pathogen was present. To have a clear identification of the Chilean isolates, the strain IMI 394944 (Cho-391) of Ch.purpureum identified by CABI (UK), was used as a reference.

The ITS-RFLP markers showed a low level of diversity in Chilean populations of Ch. purpureum and only nine (9) out of 32 ITS-/restriction enzymes combinations were able to differentiated about half of the isolates analyzed in this study.

In spite of this, the isolates were collected in the wide range of geographic zone, including south, central south and central zone of the country, sixty eight (68) out of one hundred nineteen (119) isolates showed the same genetic profile (genetic distance), indicating the low variability of the isolated that were attacking the blueberry plants. These results were confirmed by the low values of polymorphic information content and number of banding patterns present in the population studied.

Although the diversity is low, the amplification of the rDNA conserved region using specific primers for Basidiomycetes combined with the nine restriction enzymes detected some degree of polymorphisms, that were able to characterize genetically of Chilean Ch. purpureum population attacking blueberry orchards in Chile. On the other hand, when it was characterized the Ch. purpureum populations attacking other species different from blueberry, it was found that 12 isolates had identical banding profile compared with isolates collected from blueberry. These isolates were grouped together, at distance " 0 " including Cho-391 (reference strain). Therefore, more than half of the isolates collected in other species could not be differentiated from the isolates attacking blueberry.

On the contrary, some differentiation was possible to found among isolates collected in different hosts, and were located in the second cluster of the dendrogram (Fig. 4). In this group, some isolates coming from different hosts showed also identical profile with blueberry. This could mean that, with the combination for ITS-RFLP and restriction enzymes used in this study, was not possible to distinguish between populations coming from different hosts or these isolates are not specific for attacking different species.

According to the statistical analysis, there was not a statistical difference between hosts and the region where the isolates were collected. Furthermore, these results indicated that the higher percentage of variability is within each host category and collection region. These results agree with Gosselin et al. (1996), using RAPDs who did not find any relationship between ecological or host specialization, in spite of that a high variation detected within isolates. Based on an analysis with Random Amplified Microsatellite (RAMS) markers, Vartiamäki et al. (2008) found similar results analyzing five $C h$. purpureum populations from Finland and Lithuania. The results showed a higher 
variation within the studied populations (98.76\%) compared with the variation obtained among populations (1.24\%) and no statistical differences between them. In this study, a low differentiation in Ch. purpureum populations that attack blueberry could be related to the fact that this disease can be considered as a recent disease, and the technique used was not able to detect genetic variations among isolates within and between species.

The first symptoms of xylem necrosis was detected in the blueberry cultivar 'Brigitta Blue' during the 2005-2006 season in Los Lagos Region located in the south zone (France et al. 2009), and $20 \%$ of the analysed isolates in this study came from this region. It was supposed that the pressure or variability of the isolates on blueberries in this zone must be greater than the other zones, because of the origin of the symptoms of the disease, a high number orchards and a better environment for the development of the disease.

Based on these results, further studies based on other genetic analysis and identification methods of the pathogen needs to be done. For example, the sequencing of the amplified PCR, using ITS primers, their blast analysis and comparison with other species sequences deposited in a GenBank (Itoo et al. 2015). This will allowed us to confirm the identification of species and to determine its genetic structure.

Silverleaf is a potential disease that can have serious consequences for blueberry orchards and should be included in the strategic blueberry disease control programmes because the macropropagated plants in nurseries, the most common way to multiply plants, could facilitate the spread of this disease within the zone and other areas of the country.

Moreover, silverleaf could be a serious problem, since this disease has been reported in Oregon, zone of origin and natural distribution of the blueberry crop, where the plant coexists with this fungus (France et al. 2009).

\section{ACKNOWLEDGEMENTS}

The authors wish to thanks the Fondo Nacional de Desarrollo Científico y Tecnológico (FONDECYT), Project $N^{\circ} 1120978$, for financial support of this work. This study is part of this project and it corresponds to a thesis work for a Magister degree.

\section{REFERENCES}

Adair, S., Hwan, S., Breuil, C. 2002. A molecular approach for early monitoring of decay basidiomycetes in wood chips. FEMS Microbiology Letters 221: 117-122.

Balzarini, M.G., Di Rienzo, J.A. 2013. InfoGen versión 2013. Córdoba, Argentina: FCA, Universidad Nacional de Córdoba. URL http://www.info-gen.com.ar (Accessed 17 January 2017).
Becerra, V., Paredes, M., Rojo, C., France, A. 2007a. Variación intraespecífica en poblaciones chilenas de Beauveria bassiana, mediante RAPD e ITS. Agricultura Técnica (Chile) 67: 115-125

Becerra, V., Paredes, M., Rojo, C., France, A., Franco, J. 2007 b. Intraspecific differentiation of Chilean Metarhizium anisopliae var. anisopliae revealed by RAPD, SSR and ITS. Genetic and Molecular Biology 30: 89-99.

Cisterna, E., France, A. 2009. Manual de campo. Plagas, enfermedades y desórdenes fisiológicos de arándano en Chile. Boletín INIA N 189.127 pp.

Elfar, K., Torres, R., Díaz, G.A., Latorre, B.A. 2013. Characterization of Diaporthe australafricana and Diaporthe spp. associated with stem canker of blueberry in Chile. Plant Disease 97: 1042-1050.

Espinoza, J.G., Briceño, E.X., Keith, L.M., Latorre, B.A. 2008. Canker and twig dieback of blueberry caused by Pestalotiopsis spp. and a Truncatella sp. in Chile. Plant Disease 92: 1407-1414.

Espinoza, J.G., Briceño, E.X., Chavez, E.R., Úrbez-Torres, J.R., Latorre, B.A. 2009. Neufusicoccum spp. associated with stem canker and dieback of blueberry in Chile. Plant Disease 93: 1187-1194.

Excoffier, L., Smouse, P., Quattro, J. 1992. Analysis of molecular variance inferred from genetic distances among DNA haplotypes: application to human mitochondrial DNA restriction data. Genetics 131: 479-491.

Farr, D.F., Rossman, A.Y., PaLm, M.E., McCray, E.B. 2008. Fungal databases, systematic botany and mycology laboratory. In: ARS, USDA. [http://nt.ars-grin.gov/fungaldatabases/]. Accessed 3 May 2008.

France, A., Santelices, C., Buddie, A., Kirk, P. 2009. Silver leaf: first worldwide report of a new and harmful disease on blueberry. Acta Horticulturae (ISHS) 810 4: 341344. [http://www.actahort.org/books/810/810_44.htm]. Accessed 4 March 2009.

Gardes, M., Bruns, T.D. 1993. ITS primers with enhanced specificity for Basidiomycetes-application to the identification of mycorrhizae and rusts. Molecular Ecology 2: 113-118.

Gomes, E.A., Kasaya, M.C., De Barros, E.G., Borgs, A.G., Arujo, E.F. 2002. Polymorphism in the internal transcribed spacer (ITS) of the ribosomal DNA of 26 isolates of ectomycorrhizal fungi. Genetic and Molecular Biology 25: 477-483.

Gosselin, L., Jobidon, R., Bernier, L. 1996. Assessment of the genetic variation within Chondrostereum purpureum from Quebec by random amplified polymorphic DNA analysis. Mycological Research. 100: 151-158.

Itoo, Z.A, Reshi, Z.A., Basharat, Q., Majeed, S.T., Andrabi, K.I. 2015. Identification and characterization of Ectomycorrhizal Cortinarius species (Agaricales, Basidiomycetes) from temperate Kashmir Himalaya, India, by ITS barcoding. Advances in Molecular Biology. Volume 2015, Article ID 507684. http://dx.doi. org/10.1155/2015/507684. (Accessed 17 january 2017).

ItURRALDE, M.J. 2005. Identificación genética de hongos. Sociedad Micológica de Madrid. In: http:/www.socmicolmadrid. org/noti/noticias30.html. (Accessed 25 April 2005).

O’Brien, H.E., Parrent, J.L., Jackson, J.A., Moncalvo, J.M., 
VILGALYS, R. 2005. Fungal communities' analysis by largescale sequencing of environmental samples. Environmental Microbiology 71: 5544-5550.

ODEPA-CIREN. 2014. Catastro Frutícola, Principales Resultados. Región Metropolitana, Santiago. 48 pp.

ODEPA. 2014. Boletín Frutícola, Avance octubre 2014. 28 pp.

Pérez, S., Meriño-Gergichevich, C., Guerrero, J. 2014. Detection of Neufusicoccum nonquaesitum causing dieback and canker in highbush blueberry from southern Chile. Journal of Soil Science and Plant Nutrition 14: 581-588.

Prewitt, M.L., Diehl, S.V., McElroy, T., Dile, W. 2008. Comparison of general fungal and basidiomycete-specific ITS primers for identification of wood decay fungi. Forest Products Journal 58: 66-71.

PROCHILE. 2011. Mercado Internacional para arándanos frescos. Subdepartamento de información comercial, octubre 2011.

TAYlor, D.L., McCormick, M.K. 2008. Internal transcribed spacer primers and sequences for improved characterization of basidiomycetous orchid mycorrhizas. New Phytopatologist 177: 1020-1033.
Toju, H., Tanabe, A.S., Sato, H. 2012. High-coverage ITS primers for the DNA-based identification of Ascomycetes and Basidiomycetes in environmental samples. Plos One 7(7): e40863. doi:10.1371/journal.pone.0040863.

Torres, A., Lolas, M., LaBra, E. 2006. Fruticultura: Importancia de los principales patógenos en la productividad del cerezo. Villa Alegre, Chile. Instituto de Investigaciones Agropecuarias. Boletín INIA N 141.48 pp.

Vartiamäki, H., Uotila, A., Vasaitis, R., Hantula, J. 2008. Genetic diversity in Nordic and Baltic populations of Chondrostereum purpureum: a potential herbicide biocontrol agent. Forest Pathology 38: 381-393.

White, T.J., Bruns, T., Lee, S., Taylor, J. 1990. Amplification and direct sequencing of fungal ribosomal RNA genes for phylogenetics. In: Innis, M.A., Gelfand, D.H., Sminsky, J.J., White, T.J. (eds.), PCR Protocols: A guide to methods and applications, pp. 315-322. Academia Press, Inc., New York, USA.

ANNEX 1. Isolates of Chondrostereum purpureum (Cho), host and cultivar, region and zone of origin, geographic location and cluster group generated by the ITS-RFLP analysis. / Aislados of Chondrostereum purpureum (Cho), huésped y cultivar, región y zona de origen, localidad geográfica y agrupamiento basado en el análisis de ITS-RFLP.

\begin{tabular}{|c|c|c|c|c|c|c|c|c|}
\hline \multirow{2}{*}{$\mathrm{N}^{\circ}$} & \multirow{2}{*}{ IDENTIFICATION } & \multirow{2}{*}{ Host } & \multirow{2}{*}{ Cultivar } & \multirow{2}{*}{ Region } & \multirow{2}{*}{ ZONE } & \multicolumn{2}{|c|}{ CoORdinates } & \multirow{2}{*}{$\begin{array}{c}\text { MoleCUlaR } \\
\text { GROUPING }\end{array}$} \\
\hline & & & & & & LONGITUDE & LATITUDE & \\
\hline 1 & Cho-391 & Blueberry & Brigitta & Los Lagos & South & $73^{\circ} 03^{\prime} 11^{\prime \prime} \mathrm{W}$ & $40^{\circ} 31 ' 20$ 's & 1 \\
\hline 2 & Cho-450 & Blueberry & & Maule & Central-south & 7149’27.99'”W & $36^{\circ} 08^{\prime} 23.85^{\prime \prime} \mathrm{S}$ & 1 \\
\hline 3 & Cho-457 & Blueberry & & Maule & Central-south & 7149’27.99”W & $36^{\circ} 08^{\prime} 23.85^{\prime \prime} \mathrm{S}$ & 1 \\
\hline 4 & Cho-506 & Blueberry & Legacy & Los Lagos & South & $73^{\circ} 07^{\prime} 54.9$ ' W & $40^{\circ} 34^{\prime} 28.22$ 's & 1 \\
\hline 5 & Cho-571 & Blueberry & Misty & Biobío & Central-south & $72^{\circ} 30^{\prime} 02.04^{\prime \prime} \mathrm{W}$ & $37^{\circ} 27^{\prime} 35.81^{\prime \prime} \mathrm{S}$ & 2 \\
\hline 6 & Cho-578 & Blueberry & Brigitta & La Araucanía & South & $72^{\circ} 40^{\prime} 34.90 ’ \mathrm{~W}$ & $39^{\circ} 06^{\prime} 02.02 " \mathrm{~S}$ & 2 \\
\hline 7 & Cho-594 & Peach & & L.B. O'Higgins & Central & $70^{\circ} 44^{\prime} 20.27^{\prime \prime} \mathrm{W}$ & $34^{\circ} 10^{\prime} 04.99$ 'S & 1 \\
\hline 8 & Cho-607 & Apple & & Biobío & Central-south & $72^{\circ} 21^{\prime} 16.03^{\prime \prime} \mathrm{W}$ & $37^{\circ} 28^{\prime} 22.34^{\prime \prime} \mathrm{S}$ & 1 \\
\hline 9 & Cho-711 & Blueberry & Brigitta & Los Ríos & South & $72^{\circ} 22^{\prime} 51.06^{\prime \prime} \mathrm{W}$ & $40^{\circ} 07^{\prime} 28.35^{\prime \prime} \mathrm{S}$ & 1 \\
\hline 10 & Cho-712 & Blueberry & Brigitta & Los Ríos & South & $72^{\circ} 22^{\prime} 51.06^{\prime \prime} \mathrm{W}$ & $40^{\circ} 07^{\prime} 28.35^{\prime \prime} \mathrm{S}$ & 1 \\
\hline 11 & Cho-713 & Blueberry & Brigitta & Los Ríos & South & $72^{\circ} 25^{\prime} 45,5^{\prime \prime} \mathrm{W}$ & $40^{\circ} 07^{\prime} 10.4 ” \mathrm{~S}$ & 1 \\
\hline 12 & Cho-714 & Blueberry & Brigitta & Los Ríos & South & $73^{\circ} 30^{\prime} 12^{\prime \prime} \mathrm{W}$ & $40^{\circ} 18^{\prime} 58.3$ 'S & 2 \\
\hline 13 & Cho-718 & Blueberry & Brigitta & Los Lagos & South & $73^{\circ} 0 ’ 59.5^{\prime \prime} \mathrm{W}$ & $40^{\circ} 57^{\prime} 04.4^{\prime \prime} \mathrm{S}$ & 1 \\
\hline 14 & Cho-719(1) & Blueberry & Brigitta & Los Ríos & South & $72^{\circ} 38^{\prime} 47.5^{\prime \prime} \mathrm{W}$ & $40^{\circ} 12^{\prime} 53.5^{\prime \prime} \mathrm{S}$ & 2 \\
\hline 15 & Cho-720 & Blueberry & Brigitta & Biobío & Central-south & $72^{\circ} 21^{\prime} 38.48^{\prime \prime} \mathrm{W}$ & $36^{\circ} 31^{\prime} 06.42$ 's & 2 \\
\hline 16 & Cho-722 & Blueberry & Brigitta & Biobío & Central-south & $71^{\circ} 44^{\prime} 48.81^{\prime \prime} \mathrm{W}$ & $36^{\circ} 33^{\prime} 27.5^{\prime \prime} \mathrm{S}$ & 2 \\
\hline 17 & Cho-723 & Blueberry & Brigitta & Biobío & Central-south & $72^{\circ} 19^{\prime} 35.4^{\prime \prime} \mathrm{W}$ & $36^{\circ} 51^{\prime} 55^{\prime} \mathrm{S}$ & 1 \\
\hline 18 & Cho-724 & Blueberry & Brigitta & La Araucanía & South & $72^{\circ} 21^{\prime} 03.67^{\prime \prime} \mathrm{W}$ & $38^{\circ} 13^{\prime} 53.28^{\prime \prime} \mathrm{S}$ & 1 \\
\hline 19 & Cho-725 & Blueberry & Brigitta & La Araucanía & South & $72^{\circ} 21^{\prime} 03.67^{\prime \prime} \mathrm{W}$ & $38^{\circ} 13^{\prime} 53.28^{\prime \prime} \mathrm{S}$ & 2 \\
\hline 20 & Cho-728 & Blueberry & Brigitta & La Araucanía & South & $72^{\circ} 23^{\prime} 50.6$ 'W & $38^{\circ} 50^{\prime} 59.2 ” \mathrm{~S}$ & 1 \\
\hline 21 & Cho-731 & Blueberry & Brigitta & La Araucanía & South & $72^{\circ} 18^{\prime} 36.9$ ' W & $38^{\circ} 37^{\prime} 54^{\prime \prime} \mathrm{S}$ & 2 \\
\hline 22 & Cho-732 & Blueberry & Brigitta & La Araucanía & South & $72^{\circ} 19^{\prime} 23^{\prime \prime} \mathrm{W}$ & $38^{\circ} 25^{\prime} 5.9$ ' S & 1 \\
\hline 23 & Cho-733 & Blueberry & Brigitta & La Araucanía & South & $72^{\circ} 18^{\prime} 36.9$ ' W & $38^{\circ} 37^{\prime} 54^{\prime \prime} \mathrm{S}$ & 2 \\
\hline 24 & Cho-734 & Blueberry & Brigitta & La Araucanía & South & $72^{\circ} 15^{\prime \prime} 48.2^{\prime \prime} \mathrm{W}$ & $38^{\circ} 0 \prime 12.3^{\prime \prime} \mathrm{S}$ & 2 \\
\hline 25 & Cho-735 & Blueberry & Brigitta & La Araucanía & South & $72^{\circ} 29^{\prime} 30.64^{\prime \prime} \mathrm{W}$ & $38^{\circ} 20^{\prime} 14.88^{\prime \prime S}$ & 1 \\
\hline 26 & Cho-736 & Blueberry & Brigitta & Biobío & Central-south & $71^{\circ} 58^{\prime} 59.72^{\prime \prime} \mathrm{W}$ & $36^{\circ} 52^{\prime} 21.29 ’ \mathrm{~S}$ & 1 \\
\hline
\end{tabular}




\begin{tabular}{|c|c|c|c|c|c|c|c|c|}
\hline \multirow{2}{*}{$\mathrm{N}^{\circ}$} & \multirow{2}{*}{ IDENTIFICATION } & \multirow{2}{*}{ Host } & \multirow{2}{*}{ Cultivar } & \multirow{2}{*}{ REGION } & \multirow{2}{*}{ ZONE } & \multicolumn{2}{|c|}{ COORDINATES } & \multirow{2}{*}{$\begin{array}{c}\text { MOLECULAR } \\
\text { GROUPING }\end{array}$} \\
\hline & & & & & & LONGITUDE & LATITUDE & \\
\hline 27 & Cho-737 & Blueberry & Brigitta & Biobío & Central-south & $72^{\circ} 05^{\prime} 41.39^{\prime \prime} \mathrm{W}$ & $36^{\circ} 53^{\prime} 0.62$ 'S & 1 \\
\hline 28 & Cho-738 & Blueberry & Brigitta & Biobío & Central-south & $72^{\circ} 7^{\prime} 26.73^{\prime \prime} \mathrm{W}$ & $36^{\circ} 50^{\prime} 35.11$ 'S & 2 \\
\hline 29 & Cho-739 & Blueberry & Brigitta & Biobío & Central-south & $72^{\circ} 1^{\prime} 40.86^{\prime \prime} \mathrm{W}$ & $36^{\circ} 51 ' 21.29$ 'S & 2 \\
\hline 30 & Cho-740 & Blueberry & Brigitta & Biobío & Central-south & $72^{\circ} 7^{\prime} 1.64$ 'W & $36^{\circ} 29 " 9.95 " \mathrm{~S}$ & 2 \\
\hline 31 & Cho-741a & Blueberry & Brigitta & Los Ríos & South & $72^{\circ} 51^{\prime} 26,4^{\prime \prime} \mathrm{W}$ & $40^{\circ} 20^{\prime} 20.5^{\prime \prime} \mathrm{S}$ & 1 \\
\hline 32 & Cho-742 & Blueberry & Brigitta & La Araucanía & South & $72^{\circ} 40^{\prime} 59.88^{\prime \prime} \mathrm{W}$ & $38^{\circ} 15^{\prime} 00.00^{\prime \prime} \mathrm{S}$ & 2 \\
\hline 33 & Cho-743 & Blueberry & Brigitta & Los Lagos & South & $73^{\circ} 5^{\prime} 11.3^{\prime \prime} \mathrm{W}$ & $40^{\circ} 54 ’ 30.2$ 'S & 2 \\
\hline 34 & Cho-745 & Blueberry & Brigitta & Los Ríos & South & $72^{\circ} 16^{\prime} 59.1$ 'W & $39^{\circ} 34^{\prime} 12.5^{\prime \prime} \mathrm{S}$ & 2 \\
\hline 35 & Cho-747 & Blueberry & Drapper & Los Lagos & South & $73^{\circ} 5^{\prime} 14.6^{\prime \prime} \mathrm{W}$ & $40^{\circ} 54^{\prime} 51^{\prime \prime} \mathrm{S}$ & 1 \\
\hline 36 & Cho-755 & Apple & & Biobío & Central-south & $72^{\circ} 05^{\prime} 15^{\prime \prime} \mathrm{W}$ & $36^{\circ} 35^{\prime} 47^{\prime \prime} \mathrm{S}$ & 2 \\
\hline 37 & Cho-756 & Blueberry & Brigitta & Los Ríos & South & $73^{\circ} 3^{\prime} 49.6$ "'W & $39^{\circ} 36^{\prime} 57.5^{\prime \prime} \mathrm{S}$ & 1 \\
\hline 38 & Cho-757 & Blueberry & Brigitta & Los Ríos & South & $72^{\circ} 52^{\prime} 36.9^{\prime \prime} \mathrm{W}$ & $40^{\circ} 7^{\prime} 73$ 'S & 2 \\
\hline 39 & Cho-758 & Blueberry & Brigitta & Los Lagos & South & $73^{\circ} 5^{\prime} 11.3^{\prime \prime} \mathrm{W}$ & $40^{\circ} 54 ’ 30.2 ” \mathrm{~S}$ & 2 \\
\hline 40 & Cho-760 & Blueberry & Brigitta & Los Ríos & South & $72^{\circ} 53^{\prime} 54.6^{\prime \prime} \mathrm{W}$ & $40^{\circ} 13^{\prime} 16.5^{\prime \prime} \mathrm{S}$ & 2 \\
\hline 41 & Cho-766 & Blueberry & Brigitta & La Araucanía & South & $72^{\circ} 21^{\prime} 37.55^{\prime \prime} \mathrm{W}$ & $38^{\circ} 43^{\prime} 27^{\prime \prime} \mathrm{S}$ & 2 \\
\hline 42 & Cho-767 & Blueberry & Brigitta & La Araucanía & South & $72^{\circ} 35^{\prime} 31.14^{\prime \prime} \mathrm{W}$ & $38^{\circ} 57^{\prime} 43.6^{\prime \prime} \mathrm{S}$ & 1 \\
\hline 43 & Cho-768 & Blueberry & Brigitta & Biobío & Central-south & $71^{\circ} 46^{\prime} 46.89^{\prime \prime} \mathrm{W}$ & $36^{\circ} 32^{\prime} 39.84 \prime S$ & 1 \\
\hline 44 & Cho-769 & Poplar & & Biobío & Central-south & $71^{\circ} 56^{\prime} 49.62^{\prime \prime} \mathrm{W}$ & $36^{\circ} 37^{\prime} 49.34 ” S$ & 1 \\
\hline 45 & Cho-775 & Blueberry & $\begin{array}{c}\text { Blue } \\
\text { Heaven }\end{array}$ & La Araucanía & South & $72^{\circ} 39^{\prime} 6.8^{\prime \prime} \mathrm{W}$ & $39^{\circ} 6 ’ 7.5^{\prime \prime} \mathrm{S}$ & 2 \\
\hline 46 & Cho-776 & Blueberry & Brigitta & La Araucanía & South & $72^{\circ} 21^{\prime} 22.68^{\prime \prime} \mathrm{W}$ & $38^{\circ} 43^{\prime} 35.6^{\prime \prime} \mathrm{S}$ & 2 \\
\hline 47 & Cho-780 & Blueberry & Brigitta & Biobío & Central-south & $72^{\circ} 22^{\prime} 52.0 ” \mathrm{~W}$ & $37^{\circ} 20^{\prime} 34.1$ 'S & 1 \\
\hline 48 & Cho-785 & Blueberry & Brigitta & Biobío & Central-south & $71^{\circ} 56^{\prime} 49.62^{\prime \prime} \mathrm{W}$ & $36^{\circ} 37^{\prime} 49.34 ” S$ & 1 \\
\hline 49 & Cho-791a & Apple & & Maule & Central-south & $71^{\circ} 44^{\prime} 37.63^{\prime \prime} \mathrm{W}$ & $35^{\circ} 40^{\prime} 34.43 ” \mathrm{~S}$ & 2 \\
\hline 50 & Cho-791b & Apple & & Maule & Central-south & $71^{\circ} 44^{\prime} 37.63^{\prime \prime} \mathrm{W}$ & $35^{\circ} 40^{\prime} 34.43^{\prime \prime} \mathrm{S}$ & 1 \\
\hline 51 & Cho-792 & Acacia & & Biobío & Central-south & $72^{\circ} 05^{\prime} 15^{\prime \prime} \mathrm{W}$ & $36^{\circ} 35^{\prime} 47^{\prime \prime} \mathrm{S}$ & 2 \\
\hline 52 & Cho-793a & Poplar & & Biobío & Central-south & $72^{\circ} 30^{\prime} 02.04^{\prime \prime} \mathrm{W}$ & $37^{\circ} 27^{\prime} 35.81^{\prime \prime} \mathrm{S}$ & 1 \\
\hline 53 & Cho-794 & Apple & & La Araucanía & South & $72^{\circ} 31^{\prime} 09.28^{\prime \prime} \mathrm{W}$ & $37^{\circ} 37^{\prime} 44.91 ” S$ & 1 \\
\hline 54 & Cho-795 & Apricot & & Biobío & Central-south & $72^{\circ} 05^{\prime} 15^{\prime \prime} \mathrm{W}$ & $36^{\circ} 35^{\prime} 47^{\prime \prime} \mathrm{S}$ & 1 \\
\hline 55 & Cho-799 & Blueberry & Liberty & Los Ríos & South & $72^{\circ} 41^{\prime} 56^{\prime \prime} \mathrm{W}$ & $40^{\circ} 19^{\prime} 52 ” \mathrm{~S}$ & 1 \\
\hline 56 & Cho-800 & Blueberry & Brigitta & La Araucanía & South & $72^{\circ} 01^{\prime} 40.74^{\prime \prime} \mathrm{W}$ & $38^{\circ} 55^{\prime} 55.40^{\prime \prime} \mathrm{S}$ & 1 \\
\hline 57 & Cho-801 & Blueberry & Brigitta & La Araucanía & South & $72^{\circ} 23^{\prime} 45^{\prime \prime} \mathrm{W}$ & $38^{\circ} 51 ' 22$ 'S & 2 \\
\hline 58 & Cho-802 & Blueberry & Brigitta & La Araucanía & South & $72^{\circ} 23^{\prime} 45^{\prime \prime} \mathrm{W}$ & $38^{\circ} 51^{\prime} 22^{\prime \prime} \mathrm{S}$ & 2 \\
\hline 59 & Cho-803 & Blueberry & Brigitta & La Araucanía & South & $72^{\circ} 23^{\prime} 45^{\prime \prime} \mathrm{W}$ & $38^{\circ} 51^{\prime} 22^{\prime \prime} \mathrm{S}$ & 2 \\
\hline 60 & Cho-804 & Blueberry & Brigitta & La Araucanía & South & $72^{\circ} 15^{\prime} 18.1$ 'W & $39^{\circ} 0 ’ 12{ }^{\prime} \mathrm{S}$ & 2 \\
\hline 61 & Cho-805 & Blueberry & Brigitta & La Araucanía & South & $72^{\circ} 15^{\prime} 18.1$ ”W & $39^{\circ} 0 ’ 12^{\prime \prime} \mathrm{S}$ & 1 \\
\hline 62 & Cho-806 & Blueberry & Brigitta & La Araucanía & South & $72^{\circ} 15^{\prime} 18.1$ ' W & $39^{\circ} 0 \prime 12$ ' S & 1 \\
\hline 63 & Cho-807 & Blueberry & Brigitta & La Araucanía & South & $72^{\circ} 13^{\prime} 06.42^{\prime \prime} \mathrm{W}$ & $38^{\circ} 58^{\prime} 13.86^{\prime \prime} \mathrm{S}$ & 2 \\
\hline 64 & Cho-808 & Blueberry & Brigitta & La Araucanía & South & $72^{\circ} 01^{\prime} 40.74^{\prime \prime} \mathrm{W}$ & $38^{\circ} 55^{\prime} 55.40^{\prime \prime} \mathrm{S}$ & 2 \\
\hline 65 & Cho-809 & Blueberry & Brigitta & Biobío & Central-south & $72^{\circ} 00^{\prime} 47.36^{\prime \prime} \mathrm{W}$ & $37^{\circ} 07^{\prime} 19.26^{\prime \prime} \mathrm{S}$ & 1 \\
\hline 66 & Cho- 810 & Rose & $\begin{array}{l}\text { Queen } \\
\text { Elizabeth }\end{array}$ & & Central-south & $72^{\circ} 15^{\prime} 39.85^{\prime \prime} \mathrm{W}$ & $36^{\circ} 36^{\prime} 29.03 ” S$ & 1 \\
\hline 67 & Cho-811 & Blueberry & Brigitta & Los Lagos & South & $73^{\circ} 09^{\prime} 57.99^{\prime \prime} \mathrm{W}$ & $40^{\circ} 54^{\prime} 30.35 ” S$ & 2 \\
\hline 68 & Cho-812 & Blueberry & Drapper & Los Lagos & South & $73^{\circ} 09^{\prime} 57.99^{\prime \prime} \mathrm{W}$ & $40^{\circ} 54^{\prime} 30.35^{\prime \prime} \mathrm{S}$ & 2 \\
\hline 69 & Cho-813 & Blueberry & Liberty & La Araucanía & South & $71^{\circ} 47^{\prime} 14.19^{\prime \prime} \mathrm{W}$ & $40^{\circ} 05^{\prime} 05.19$ 'S & 1 \\
\hline 70 & Cho-814 & Blueberry & Brigitta & La Araucanía & South & $72^{\circ} 15^{\prime} 37.5^{\prime \prime} \mathrm{W}$ & $39^{\circ} 11^{\prime} 46^{\prime \prime} \mathrm{S}$ & 2 \\
\hline 71 & Cho-815 & Blueberry & Brigitta & La Araucanía & South & $72^{\circ} 15^{\prime} 37.5^{\prime \prime} \mathrm{W}$ & $39^{\circ} 11^{\prime} 46^{\prime \prime} \mathrm{S}$ & 2 \\
\hline 72 & Cho-816 & Blueberry & Brigitta & La Araucanía & South & $72^{\circ} 15^{\prime} 37.5^{\prime \prime} \mathrm{W}$ & $39^{\circ} 11^{\prime} 46^{\prime \prime} \mathrm{S}$ & 1 \\
\hline 73 & Cho-817 & Blueberry & Brigitta & La Araucanía & South & $72^{\circ} 15^{\prime} 19^{\prime \prime} \mathrm{W}$ & $38^{\circ} 40^{\prime} 17,4$ 's & 1 \\
\hline 74 & Cho-818 & Blueberry & Brigitta & La Araucanía & South & $72^{\circ} 15^{\prime} 19^{\prime \prime} \mathrm{W}$ & $38^{\circ} 40^{\prime} 17.4^{\prime \prime} \mathrm{S}$ & 1 \\
\hline
\end{tabular}




\begin{tabular}{|c|c|c|c|c|c|c|c|c|}
\hline \multirow{2}{*}{$\mathrm{N}^{\circ}$} & \multirow{2}{*}{ IDENTIFICATION } & \multirow{2}{*}{ Host } & \multirow{2}{*}{ Cultivar } & \multirow{2}{*}{ REgion } & \multirow{2}{*}{ ZONE } & \multicolumn{2}{|c|}{ COORDINATES } & \multirow{2}{*}{$\begin{array}{l}\text { MOLECULAR } \\
\text { GROUPING }\end{array}$} \\
\hline & & & & & & LONGITUDE & LATITUDE & \\
\hline 75 & Cho-819 & Blueberry & Brigitta & La Araucanía & South & $72^{\circ} 15^{\prime} 19^{\prime \prime} \mathrm{W}$ & $38^{\circ} 40^{\prime} 17,4$ 'S & 2 \\
\hline 76 & Cho-822 & Blueberry & Liberty & La Araucanía & South & $72^{\circ} 23^{\prime} 45^{\prime \prime} \mathrm{W}$ & $38^{\circ} 51^{\prime} 2.2{ }^{\prime \prime} \mathrm{S}$ & 2 \\
\hline 77 & Cho- 823 & Blueberry & Brigitta & La Araucanía & South & $72^{\circ} 40^{\prime} 34.90^{\prime \prime} \mathrm{W}$ & $39^{\circ} 06^{\prime} 02.02 ” S$ & 2 \\
\hline 78 & Cho-825 & Blueberry & Brigitta & Los Lagos & South & $73^{\circ} 07^{\prime} 54.90^{\prime \prime} \mathrm{W}$ & $40^{\circ} 34 ’ 28.22 ” \mathrm{~S}$ & 1 \\
\hline 79 & Cho-826 & Blueberry & Liberty & La Araucanía & South & $71^{\circ} 47^{\prime} 14.19^{\prime \prime} \mathrm{W}$ & $40^{\circ} 05^{\prime} 05.19 ” \mathrm{~S}$ & 2 \\
\hline 80 & Cho-827 & Blueberry & Brigitta & Los Lagos & South & $73^{\circ} 07^{\prime} 54.90^{\prime \prime} \mathrm{W}$ & $40^{\circ} 34^{\prime} 28.22 ” \mathrm{~S}$ & 2 \\
\hline 81 & Cho-828 & Blueberry & Brigitta & Los Lagos & South & $73^{\circ} 3^{\prime} 36.1^{\prime \prime} \mathrm{W}$ & $40^{\circ} 31 ' 51.7$ 's & 2 \\
\hline 82 & Cho-831 & Blueberry & Brigitta & La Araucanía & South & $72^{\circ} 40^{\prime} 34.90^{\prime \prime} \mathrm{W}$ & $39^{\circ} 06^{\prime} 02.02 ” S$ & 2 \\
\hline 83 & Cho-832 & Blueberry & Brigitta & La Araucanía & South & $72^{\circ} 33^{\prime} 21.6^{\prime \prime} \mathrm{W}$ & $39^{\circ} 22^{\prime} 19.3$ "'S & 1 \\
\hline 84 & Cho-836 & Blueberry & Brigitta & La Araucanía & South & $72^{\circ} 37^{\prime} 53.45^{\prime \prime} \mathrm{W}$ & $39^{\circ} 22^{\prime} 05.23^{\prime \prime} \mathrm{S}$ & 2 \\
\hline 85 & Cho-837 & Blueberry & Brigitta & La Araucanía & South & $72^{\circ} 13^{\prime} 27.99^{\prime \prime} \mathrm{W}$ & $38^{\circ} 40^{\prime} 03.79 ” \mathrm{~S}$ & 1 \\
\hline 86 & Cho- 838 & Blueberry & Brigitta & La Araucanía & South & $72^{\circ} 13^{\prime} 27.99$ ’W & $38^{\circ} 40^{\prime} 03.79$ 'S & 1 \\
\hline 87 & Cho-839 & Blueberry & Brigitta & Los Lagos & South & $73^{\circ} 07^{\prime} 54.90^{\prime \prime} \mathrm{W}$ & $40^{\circ} 34^{\prime} 28.22 ” \mathrm{~S}$ & 1 \\
\hline 88 & Cho- 840 & Blueberry & Brigitta & Los Lagos & South & $73^{\circ} 07^{\prime} 54.90^{\prime \prime} \mathrm{W}$ & $40^{\circ} 34^{\prime} 28.22 ” \mathrm{~S}$ & 1 \\
\hline 89 & Cho-841 & Blueberry & Brigitta & La Araucanía & South & $72^{\circ} 40^{\prime} 34.90^{\prime \prime} \mathrm{W}$ & $39^{\circ} 06^{\prime} 02.02 ” \mathrm{~S}$ & 1 \\
\hline 90 & Cho-842 & Blueberry & Brigitta & La Araucanía & South & $72^{\circ} 01^{\prime} 40.74^{\prime \prime} \mathrm{W}$ & $38^{\circ} 55^{\prime} 55.40 ” \mathrm{~S}$ & 1 \\
\hline 91 & Cho- 843 & Blueberry & Brigitta & Los Lagos & South & $73^{\circ} 07^{\prime} 54.90^{\prime \prime} \mathrm{W}$ & $40^{\circ} 34 ’ 28.22 ” \mathrm{~S}$ & 2 \\
\hline 92 & Cho-844 & Blueberry & Brigitta & Los Lagos & South & $73^{\circ} 07^{\prime} 54.90^{\prime \prime} \mathrm{W}$ & $40^{\circ} 34^{\prime} 28.22 ” \mathrm{~S}$ & 2 \\
\hline 93 & Cho-845 & Blueberry & Duke & Biobío & Central-south & $72^{\circ} 06^{\prime} 04.75^{\prime \prime} \mathrm{W}$ & $36^{\circ} 50^{\prime} 41.97 ” S$ & 1 \\
\hline 94 & Cho-846 & Blueberry & Brigitta & Biobío & Central-south & $72^{\circ} 06^{\prime} 04.75^{\prime \prime} \mathrm{W}$ & $36^{\circ} 50^{\prime} 41.97 ” S$ & 2 \\
\hline 95 & Cho-849 & Blueberry & Brigitta & Los Ríos & South & $72^{\circ} 22^{\prime} 51.06^{\prime \prime} \mathrm{W}$ & $40^{\circ} 07^{\prime} 28.35^{\prime \prime} \mathrm{S}$ & 1 \\
\hline 96 & Cho- 850 & Blueberry & Brigitta & Los Ríos & South & $72^{\circ} 22^{\prime} 51.06^{\prime \prime} \mathrm{W}$ & $40^{\circ} 07^{\prime} 28.35^{\prime \prime} \mathrm{S}$ & 1 \\
\hline 97 & Cho-851 & Blueberry & Brigitta & Los Ríos & South & $72^{\circ} 22^{\prime} 51.06^{\prime \prime} \mathrm{W}$ & $40^{\circ} 07^{\prime} 28.35^{\prime \prime} \mathrm{S}$ & 2 \\
\hline 98 & Cho-852 & Blueberry & Brigitta & Los Ríos & South & $71^{\circ} 47^{\prime} 14.19^{\prime \prime} \mathrm{W}$ & $40^{\circ} 05^{\prime} 05.19 ” \mathrm{~S}$ & 2 \\
\hline 99 & Cho-860 & Blueberry & Brigitta & La Araucanía & South & $72^{\circ} 13 ’ 27.99 ’ \mathrm{~W}$ & $38^{\circ} 40^{\prime} 03.79^{\prime \prime} \mathrm{S}$ & 2 \\
\hline 100 & Cho-861 & Blueberry & Brigitta & Los Lagos & South & $73^{\circ} 5^{\prime} 11.3^{\prime \prime} \mathrm{W}$ & $40^{\circ} 54^{\prime} 30.2{ }^{\prime \prime} \mathrm{S}$ & 2 \\
\hline 101 & Cho-863 & Blueberry & Brigitta & Los Lagos & South & $73^{\circ} 5^{\prime} 11.3 ” \mathrm{~W}$ & $40^{\circ} 54^{\prime} 30.2 ” \mathrm{~S}$ & 1 \\
\hline 102 & Cho-864 & Blueberry & Brigitta & La Araucanía & South & $72^{\circ} 13 ’ 27.99$ ’W & $38^{\circ} 40^{\prime} 03.79^{\prime \prime} \mathrm{S}$ & 1 \\
\hline 103 & Cho-865 & Blueberry & Bluecrop & Los Lagos & South & $73^{\circ} 5^{\prime} 11.3^{\prime \prime} \mathrm{W}$ & $40^{\circ} 54^{\prime} 30.2^{\prime \prime} \mathrm{S}$ & 1 \\
\hline 104 & Cho-867 & Blueberry & Brigitta & Los Lagos & South & $73^{\circ} 5^{\prime} 11.3^{\prime \prime} \mathrm{W}$ & $40^{\circ} 54^{\prime} 30.2{ }^{\prime} \mathrm{S}$ & 2 \\
\hline 105 & Cho-868 & Blueberry & Brigitta & Valparaíso & Central & $71^{\circ} 23^{\prime} 49.02^{\prime \prime} \mathrm{W}$ & $33^{\circ} 17^{\prime} 38.17^{\prime \prime} \mathrm{S}$ & 1 \\
\hline 106 & Cho-869 & Eucalyptus & E. globulus & Biobío & Central-south & $71^{\circ} 47^{\prime} 00.79^{\prime \prime} \mathrm{W}$ & $36^{\circ} 42^{\prime} 02.34 ” S$ & 1 \\
\hline 107 & Cho- 870 & Blueberry & Brigitta & Biobío & Central-south & $73^{\circ} 22^{\prime} 43.7^{\prime \prime} \mathrm{W}$ & $37^{\circ} 43^{\prime} 25^{\prime \prime} \mathrm{S}$ & 1 \\
\hline 108 & Cho-871 & Peach & Canning & Valparaíso & Central & $71^{\circ} 13^{\prime} 46.87^{\prime \prime} \mathrm{W}$ & $32^{\circ} 49^{\prime} 20.71 ” S$ & 1 \\
\hline 109 & Cho-872 & Peach & Nectarine & Valparaíso & Central & $71^{\circ} 13^{\prime} 46.87^{\prime \prime} \mathrm{W}$ & $32^{\circ} 49^{\prime} 20.71 ” S$ & 2 \\
\hline 110 & Cho-874 & Cherry & & La Araucanía & South & $72^{\circ} 22^{\prime} 38.90^{\prime \prime} \mathrm{W}$ & $38^{\circ} 40^{\prime} 38.49^{\prime \prime} \mathrm{S}$ & 2 \\
\hline 111 & Cho-875 & Blueberry & Brigitta & La Araucanía & South & $72^{\circ} 35^{\prime} 4.19^{\prime \prime} \mathrm{W}$ & $38^{\circ} 44^{\prime} 2.07^{\prime \prime} \mathrm{S}$ & 1 \\
\hline 112 & Cho-876 & Blueberry & Brigitta & La Araucanía & South & $72^{\circ} 35^{\prime} 4.19^{\prime \prime} \mathrm{W}$ & $38^{\circ} 44^{\prime} 2.07^{\prime \prime S}$ & 2 \\
\hline 113 & Cho- 880 & Blueberry & Drapper & Los Lagos & South & $73^{\circ} 03^{\prime} 11^{\prime \prime} \mathrm{W}$ & $40^{\circ} 31 ' 20^{\prime \prime} \mathrm{S}$ & 1 \\
\hline 114 & Cho-882 & Blueberry & Brigitta & La Araucanía & South & $72^{\circ} 37^{\prime} 53.45^{\prime \prime} \mathrm{W}$ & $39^{\circ} 22^{\prime} 05.23^{\prime \prime} \mathrm{S}$ & 1 \\
\hline 115 & Cho- 883 & Blueberry & Brigitta & La Araucanía & South & $72^{\circ} 37^{\prime} 53.45^{\prime \prime} \mathrm{W}$ & $39^{\circ} 22^{\prime} 05.23^{\prime \prime} \mathrm{S}$ & 1 \\
\hline 116 & Cho-905 & Cherry & Lapins & Biobío & Central-south & $72^{\circ} 06^{\prime} 08.72^{\prime \prime} \mathrm{W}$ & $36^{\circ} 36^{\prime} 33.67^{\prime} \mathrm{S}$ & 2 \\
\hline 117 & Cho-917 & Apple & Fuji & Biobío & Central-south & $72^{\circ} 06^{\prime} 08.72^{\prime \prime} \mathrm{W}$ & $36^{\circ} 36^{\prime} 33.67^{\prime \prime} \mathrm{S}$ & 2 \\
\hline 118 & Cho-924 & Apple & $\begin{array}{l}\text { Granny } \\
\text { Smith }\end{array}$ & L.B. O'Higgins & Central & $70^{\circ} 43^{\prime} 59.88^{\prime \prime} \mathrm{W}$ & $34^{\circ} 04^{\prime} 00.12^{\prime \prime} \mathrm{S}$ & 1 \\
\hline 119 & Cho-927 & Pistachio & & L.B. O'Higgins & Central & $70^{\circ} 50^{\prime} 04.95^{\prime \prime} \mathrm{W}$ & $34^{\circ} 20^{\prime} 06.13^{\prime \prime} \mathrm{S}$ & 1 \\
\hline
\end{tabular}

Recibido: 05.01.2016

Aceptado: 20.05.2017 